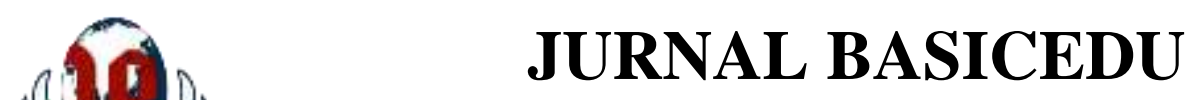

Volume 6 Nomor 1 Tahun 2022 Halaman 1185 - 1194

Research \& Learning in Elementary Education

https://jbasic.org/index.php/basicedu

\title{
Penerapan Perilaku Hidup Bersih dan Sehat (PHBS) Mahasiswa PGSD di Era Pandemi Covid-19
}

\author{
Fitriyeni $^{\otimes}$
}

Program Studi Pendidikan Guru Sekolah Dasar, Universitas Islam Riau, Indonesia

E-mail: fitriyeni@edu.uir.ac.id

\begin{abstract}
Abstrak
Tujuan penelitian ini adalah untuk mendeskripsikan Perilaku hidup bersih dan sehat (PHBS) mahasiswa PGSD FKIP UIR di era pandemi covid-19, dengan demikian diharapkan penularan wabah virus covid-19 ini akan semakin menurun bahkan bisa hilang jika setiap individu sadar, peduli, dengan menerapkan PHBS ini didalam kehidupannya. Penelitian ini dilaksanakan di Universitas Islam Riau dan sampel dalam penelitian ini adalah mahasiswa PGSD semester 2 yang berjumlah sekitar 240 mahasiswa. Penelitian ini merupakan deskritif kuantitatif. Pengumpulan data dilakukan dengan menggunakan alat ukur berupa lembar kuisioner berskala Likert. Teknik analisa data yang digunakan dalam penelitian ini adalah dekriptif kuantitatif. Setelah diadakan penelitian tentang Penerapan perilaku hidup bersih dan sehat (PHBS) Mahasiswa PGSD FKIP UIR di era pandemi covid-19. Hasil penelitian dari analisis menunjukkan hasil 74,47\%, dimana hasil ini pada kategori sangat baik. Sehingga dapat disimpulkan bahwa penerapan perilaku hidup bersih dan sehat (PHBS) Mahasiswa PGSD FKIP di Era Pandemi Covid-19 sudah sangat baik.
\end{abstract}

Kata Kunci: Perilaku Hidup Bersih dan Sehat, Covid-19.

Abstract

This study aims todescribe the Clean and Healthy Life Behavior (PHBS) of PGSD FKIP UIR students in the era of the covid-19 pandemic, thus it is hoped that the transmission of this covid-19 virus outbreak will decrease even if every individual is aware, cares, by implementing PHBS is in his life. This research was conducted at the Islamic University of Riau and the sample in this study were PGSD second semester students, totaling about 240 students. This research is a quantitative descriptive. Data was collected using a measuring instrument in the form of a Likert scale questionnaire. The data analysis technique used in this research is quantitative descriptive. After conducting research on the application of clean and healthy living behavior (PHBS) PGSD FKIP UIR students in the era of the covid-19 pandemic. The results of the analysis showed the results of $74.47 \%$, where these results were in the very good category. So it can be concluded that the implementation of clean and healthy living behavior (PHBS) for PGSD FKIP students in the Covid-19 Pandemic Era has been very good.

Keywords:Clean and Healthy Lifestyle, Covid-19.

Copyright (c) 2022 Fitriyeni

$\triangle$ Corresponding author :

Email : fitriyeni@edu.uir.ac.id

DOI $\quad:$ https://doi.org/10.31004/basicedu.v6i1.2153 

Fitriyeni

DOI: https://doi.org/10.31004/basicedu.v6i1.2153

\section{PENDAHULUAN}

Saat ini seluruh dunia sedang mengalami wabah yang disebabkan oleh virus covid-19, virus ini pertama kali berasal dari negara cina pada awal Desember 2019. Covid-19 adalah suatu wabah yang dapat menyebabkan penyakit menular berupa infeksi pada saluran pernapasan manusia yang disebabkan oleh virus. Tetapi saat ini virus covid-19 telah menyebar keseluruh dunia termasuk di Indonesia. Di Indonesia sendiri per tanggal 14 Oktober 2021 kasus covid-19 menunjukan 4.233.014 kasus terkonfirmasi (Kemenkes RI, 2021) ini menunjukan bahwa penyebaran virus ini sangat cepat terjadi. Penyakit yang disebabkan oleh virus sangat cepat penularannya, siapa saja bisa terkena virus ini, mulai bayi sampai manula. Adapun orang yang rentan terkena virus ini adalah orang yang daya imunitasnya rendah serta yang memiliki riwayat penyakit seperti: gangguan saluran pernapasan, diabetes, kanker, liver ataupun penyakit berat lainnya.

Pola penyebaran virus covid-19 inidapat terjadi karena adanya perpindahan dari manusia ke manusia melalui droplet yang dikeluarkan dari batuk dan bersin (Huang et al., 2020). Hal ini sejalan dengan yang dinyatakan oleh (Direktur Jenderal P2P, 2020) bahwa covid-19 ditularkan melalui kontak antara droplet bukan melalui tranmisi udara, individu yang beresiko terkena covid-19 adalah orang yang berhubungan dekat dengan orang yang terkonfirmasi ataupun orang yang sedang merawat pasien covi-19. Adapun cara pencegahan yang paling efektif dilingkungan masyarakat adalah sebagai berikut ini:

1. Menjaga kebersihan tangan dengan handsanitizer jika tidak terlihat kotor, dan dengan mencuci tangan jika terlihat kotor.

2. Hindari menyentuh mata, hidung, dan mulut.

3. Terapkan etika batuk dan bersin dengan menutup hidung dan mulut dengan lengan atas bagian dalam atau tisu, dan buanglah tisu ketempat sampah.

4. Pakailah masker medis jika memiliki gejala pernapasan dan melakukan kebersihan tangan setelah membuang masker.

5. Menjaga jarak minimal 1 meter dari orang yang mengalami gejala gangguan pernapasan.

Salah satu cara yang paling efektif untuk pencegahan virus ini adalah dengan menerapkan protokol kesehatan seperti yang dianjurkan oleh pemerintah yaitu menerapkan $3 \mathrm{M}: 1$. memakai masker, 2 . mencuci tangan di air mengalir dengan menggunakan sabun, 3. Menghindari kerumunan. Tentunya hal ini bisa terwujud dengan menerapkan perilaku hidup bersih dan sehat (PHBS) didalam kehidupan sehari-hari. PHBS merupakan sejumlah perilaku yang dilakukan atas dasar kesadaran pribadi, yang menjadikan individu, keluarga, kelompok atau masyarakat mampu menolong dirinya sendiri (mandiri) di bidang kesehatan dan berperan aktif dalam mewujudkan kesehatan masyarakat (Kemenkes, 2011).

Secara umum perilaku hidup bersih dan sehat bermanfaat untuk meningkatkan kesadaran masyarakat untuk mau dan mampu menjalankan hidup bersih dan sehat (RI, n.d.), dengan perilaku hidup bersih dan sehat dapat menghindari setiap individu terhadap berbagai serangan penyakit terutama yang disebabkan oleh virus dan bakteri. Adapun indikator perilaku hidup bersih dan sehat terdiri dari berbagai tatanan menurut (RI, n.d.)yakni: tatanan rumah tangga, institusi pendidikan, tempat kerja, tempat umum, fasilitas pelayanan kesehatan, adapun indikator perilaku hidup bersih dan sehat pada tatanan pendidikan adalah sebagai berikut ini:

1. Mencuci tangan menggunakan sabun.

2. Mengonsumsi makanan dan minuman sehat.

3. Menggunakan jamban sehat.

4. Membuang sampah ditempat sampah.

5. Tidak merokok.

6. Tidak mengkonsumsi narkotika dan alcohol, psikotropika dan zat adiktif lainnya.

7. Tidak meludah sembarang tempat. 

Fitriyeni

DOI: https://doi.org/10.31004/basicedu.v6i1.2153

8. Memberantas jentik nyamuk dll.

Salah satu dampak terbesar yang disebabkan oleh virus covid-19 adalah dalam dunia pendidikan. di Indonesia sendiri seluruh kegiatan proses pendidikan dilaksanakan secara daring maupun luring ini untuk mencegah penyebaran virus covid-19 mulai dari tingkat TK sampai perguruan tinggi. Pembelajaran daring ini terpaksa harus diterapkan untuk memutus rantai penyebaran virus covid-19. Ada berbagai dampak yang dirasakan dalam pembelajaran daring ini seperti hasil penelitian dari yang dilakukan oleh (Argaheni, 2020) adapun dampak dari perkuliahan daring yaitu: mahasiswa menjadi pasif, kurang kreatif dan produktif, penumpukan informasi/konsep pada mahasiswa yang kurang bermanfaat, mahasiswa mengalami stress, peningkatan kemampuan literasi bahasa mahasiswa. Penelitian serupa juga dilakukan oleh (Sari et al., 2021) dimana hasil penelitiannya menunjukan bahwa proses pembelajaran selama pandemi berubah dengan menggunakan pembelajaran jarak jauh, dan ini memberikan dampak kepada guru yang kurang maksimal dalam memberikan materi pembelajaran kepada siswa dan terganggunya proses pembelajaran yang menyebankan tidak tercapainya tujuan pembelajaran, sehingga materi menjadi tidak tuntas, penggunaan media dalam pembelajaran tidak maksimal, penilaian siswa pun hanya sebatas kognitif saja.

Jika kondisi ini dibiarkan dalam jangka waktu yang lama tentunya akan terjadi kemerosotan didalam dunia pendidikan khususnya di Indonesia. Untuk itu pencegahan dari virus covid-19 ini harus segera ditangani dengan tepat. Adapun upaya yang dapat dilakukan yaitu dengan penerapan perilaku hidup bersih dan sehat, seperti penelitian yang dilakukan (Nengsi et al., 2021) yaitu hubungan perilaku hidup bersih dan sehat terhadap kejadian covid-19 dimana hasil penelitiannya bahwa perilaku hidup bersih dan sehat dalam mencegah covid-19 sudah lumayan baik. Selanjutnya penelitian yang dilakukan oleh (Daniyanti, 2020) yaitu analisis perilaku hidup bersih dan sehat dalam pencegahan penularan covid-19 dengan hasil penelitian menunjukan bahwa sebagian besar dosen stikes Ngudia Husada Madura sudah menerapkan perilaku hidup bersih dan sehat dengan kategori sangat tinggi, perilaku pencegahan terhadap penularan covid-19 kategori sangat tinggi.

Di Universitas Islam Riau penyebaran covid-19 ini pernah berada dalam situasi yang cukup memprihatinkan, dimana Universitas Islam Riau pernah melakukan lockdown untuk pencegahan virus covid19 ini, karena terdapat karyawan dan dosen yang terpapar virus ini. Untuk pencegahan penyebaran covid-19 di lingkungan Universitas Islam Riau khususnya pada mahasiswa FKIP PGSD Universitas Islam Riau perlu untuk dilakukan gambaran penerapan perilaku hidup bersih dan sehat mahasiswa untuk mencegah penyebaran covid-19. Diharapkan berdasarkan hasil penelitian ini dapat memberikan gambaran perilaku hidup bersih dan sehat mahasiswa PGSD Universitas Islam Riau, sehingga dapat ditentukan langkah-langkah kebijakan yang akan ditentuan dalam hal pencegahan penyebaran virus covid-19 di lingkungan mahasiswa PGSD FKIP UIR khususnya. Dan dengan demikian jika penyebaran virus covid-19 ini dapat diminimalkan tentunya pembelajaran tatap muka akan segera bisa kita lakukan.

\section{METODE}

Penelitian ini adalah penelitian survey deskriptif kuantitatif. Pengumpulan data dilakukan dengan menggunakan alat ukur berupa lembar kuisioner berskala Likert. Teknik analisa data yang digunakan dalam penelitian ini adalah survey dekriptif kuantitatif. Sumber data dan informasi diperoleh dengan menggunakan angket yang disajikan dalam bentuk google form, kemudian disebarluaskan kepada sampel yaitu mahasiswa PGSD FKIP UIR yang berjumlah 216 mahasiswa. Sebelum disebarluaskan angket divalidasi dan direvisi oleh ahli, kemudian angket disebarluaskan. Setelah angket disebarluaskan maka hasilnya dianalisis secara deskriptif kuantitatif untuk melihat penerapan perilaku hidup bersih dan sehat (PHBS) Mahasiswa PGSD FKIP UIR di era pandemi covid-19. Statistik deskritif merupakan gambaran hasil penelitian yang diteliti 
1188 Penerapan Perilaku Hidup Bersih dan Sehat (PHBS) Mahasiswa PGSD di Era Pandemi Covid-19Fitriyeni

DOI: https://doi.org/10.31004/basicedu.v6i1.2153

melalui sampel atau populasi aslinya, tanpa melakukan analisis dan membuat kesimpulan yang berlaku untuk umum, (Sugiyono, 2017). Untuk lebih jelasnya penelitian ini dapat digambarkan melalui bagan berikut ini.

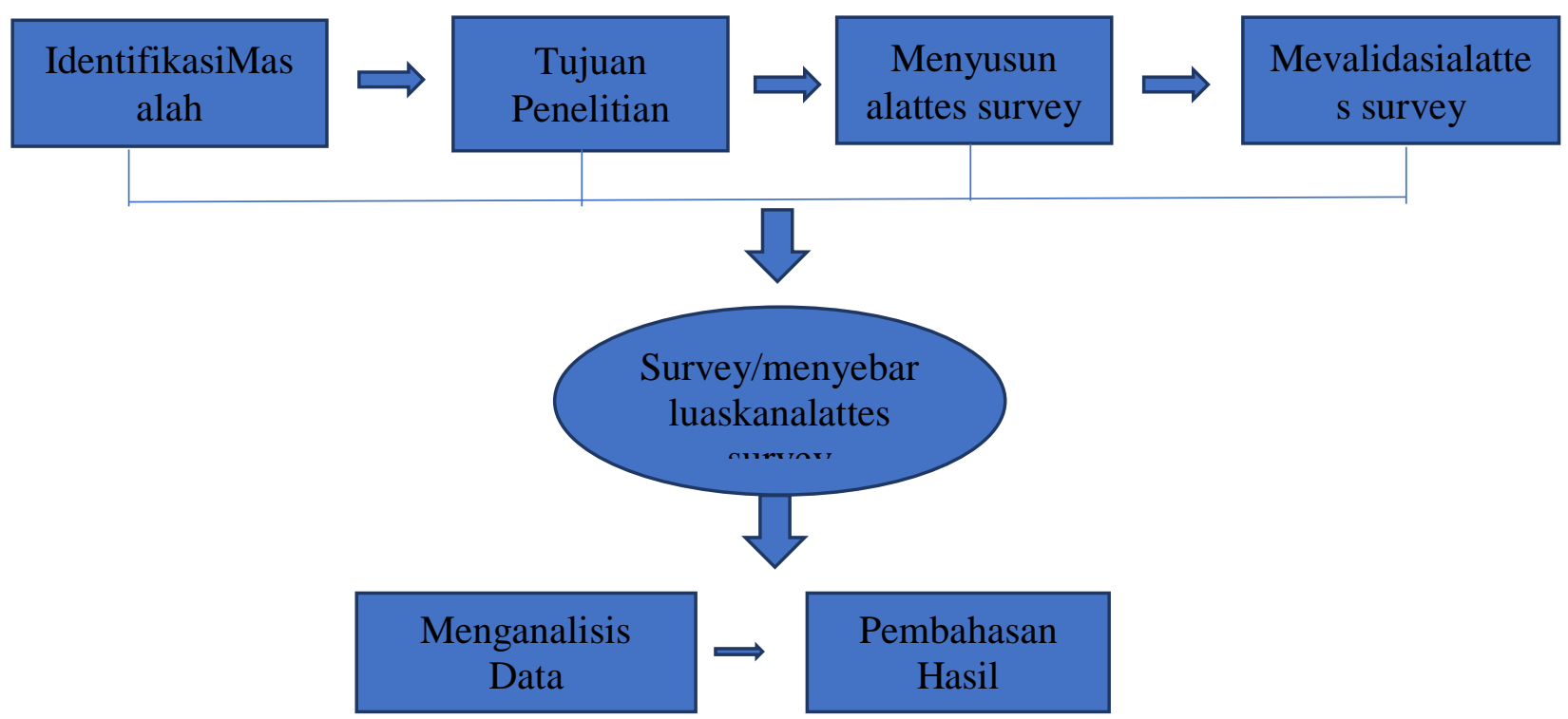

Gambar Desain Penelitian

\section{HASIL DAN PEMBAHASAN}

Berdasarkan data dan informasi yang diperoleh dari lapangan kemudian diolah dengan analisis deskriptif, berpedoman pada tujuan dan pertanyaan penelitian yang disebarkan melalui angket, maka dapat diketahui analisis ini mencakupi beberapa variabel yang diteliti. Untuk mendapatkan data tentang Penerapan perilaku hidup bersih dan sehat (PHBS) Mahasiswa PGSD FKIP UIR di era pandemi covid-19. Beberapa faktor dari PHBS yang terdiri dari indikator makanan sehat, olahraga teratur, sering cuci tangan, hindari menyentuh wajah, penggunaan masker, istirahat cukup, etika batuk dan bersin, menjaga kebersihan lingkungan, dan jaga jarak aman (RI, n.d.). Dimana untuk indikator ini terdapat 28 pertanyaan dengan 4 kategori jawaban yang dipilih responden atau sampel yaitu Selalu (SL), Sering (SR), Kadang-Kadang (KD) dan Tidak Pernah (TP) serta dengan 216 orang sampel. Untuk lebih jelasnya dapat dilihat pada Tabel di bawah ini.

Tabel 5

\section{Distribusi Frekuensi Penerapan Perilaku Hidup Sehat Mahasiswa PGSD FKIP UIR}

\begin{tabular}{|c|c|c|c|c|c|c|c|c|c|c|c|c|c|c|c|c|}
\hline \multirow{3}{*}{ Variabel } & \multirow{3}{*}{ Indikator } & \multirow{3}{*}{$\begin{array}{l}\text { No } \\
\text { Soal }\end{array}$} & \multicolumn{10}{|c|}{ Kategori Jawaban } & \multirow{3}{*}{ SCR } & \multirow{3}{*}{ SI } & \multirow{3}{*}{ SNI } & \multirow{3}{*}{ Kategori } \\
\hline & & & \multicolumn{2}{|c|}{ SL } & \multicolumn{2}{|c|}{$\mathrm{Sr}$} & \multicolumn{2}{|c|}{ Kd } & \multicolumn{2}{|c|}{ Tp } & \multicolumn{2}{|c|}{ Jumlah } & & & & \\
\hline & & & $\mathbf{F}$ & $\%$ & $\mathbf{F}$ & $\%$ & $\mathbf{F}$ & $\%$ & $\mathbf{F}$ & $\%$ & $\mathbf{F}$ & $\%$ & & & & \\
\hline \multirow{7}{*}{$\begin{array}{l}\text { Penerapan } \\
\text { perilaku } \\
\text { hidup } \\
\text { bersih dan } \\
\text { sehat } \\
\text { (PHBS) } \\
\text { Mahasiswa } \\
\text { PGSD } \\
\text { FKIP UIR } \\
\text { di era } \\
\text { pandemi }\end{array}$} & \multirow[t]{6}{*}{$\begin{array}{l}\text { Makanan } \\
\text { Sehat }\end{array}$} & 1 & 88 & 40,7 & 56 & 25,9 & 70 & 32,4 & 0 & 0 & 216 & 100 & 660 & 864 & 76,39 & $\begin{array}{c}\text { Sangat } \\
\text { Baik }\end{array}$ \\
\hline & & 2 & 131 & 60,6 & 54 & 25 & 29 & 13,4 & 0 & 0 & 216 & 100 & 744 & 864 & 86,11 & $\begin{array}{l}\text { Sangat } \\
\text { Baik }\end{array}$ \\
\hline & & 3 & 167 & 77,3 & 46 & 21,3 & 0 & 0 & 0 & 0 & 216 & 100 & 806 & 864 & 93,29 & $\begin{array}{l}\text { Sangat } \\
\text { Baik }\end{array}$ \\
\hline & & 4 & 91 & 42,1 & 82 & 38 & 42 & 19,4 & 0 & 0 & 216 & 100 & 694 & 864 & 80,32 & $\begin{array}{l}\text { Sangat } \\
\text { Baik }\end{array}$ \\
\hline & & 5 & 0 & 0 & 0 & 0 & 44 & 20,4 & 160 & 74,1 & 216 & 100 & 248 & 864 & 28,70 & Cukup \\
\hline & & 6 & 24 & 11,1 & 46 & 21,3 & 134 & 62 & 0 & 0 & 216 & 100 & 502 & 864 & 58,10 & Baik \\
\hline & Olahraga & 7 & 31 & 14,4 & 53 & 24,5 & 124 & 57,4 & 0 & 0 & 216 & 100 & 531 & 864 & 61,46 & Baik \\
\hline
\end{tabular}


1189 Penerapan Perilaku Hidup Bersih dan Sehat (PHBS) Mahasiswa PGSD di Era Pandemi Covid-19Fitriyeni

DOI: https://doi.org/10.31004/basicedu.v6i1.2153

\begin{tabular}{|c|c|c|c|c|c|c|c|c|c|c|c|c|c|c|c|c|}
\hline \multirow[t]{21}{*}{ covid-19 } & Teratur & 8 & 17 & 7,9 & 25 & 11,6 & 147 & 68,1 & 27 & 12,5 & 216 & 100 & 464 & 864 & 53,70 & Baik \\
\hline & $\begin{array}{l}\text { Sering Cuci } \\
\text { Tangan }\end{array}$ & 9 & 145 & 67,1 & 60 & 27,8 & 0 & 0 & 0 & 0 & 216 & 100 & 760 & 864 & 87,96 & $\begin{array}{c}\text { Sangat } \\
\text { Baik }\end{array}$ \\
\hline & & 10 & 176 & 81,5 & 36 & 16,7 & 0 & 0 & 0 & 0 & 216 & 100 & 812 & 864 & 93,98 & $\begin{array}{c}\text { Sangat } \\
\text { Baik }\end{array}$ \\
\hline & & 11 & 194 & 89,9 & 21 & 9,7 & 0 & 0 & 0 & 0 & 216 & 100 & 839 & 864 & 97,11 & $\begin{array}{c}\text { Sangat } \\
\text { Baik }\end{array}$ \\
\hline & & 12 & 148 & 68,5 & 57 & 26,4 & 0 & 0 & 0 & 0 & 216 & 100 & 763 & 864 & 88,31 & $\begin{array}{c}\text { Sangat } \\
\text { Baik }\end{array}$ \\
\hline & $\begin{array}{l}\text { Hindari } \\
\text { menyentuh } \\
\text { wajah }\end{array}$ & 13 & 117 & 54,2 & 75 & 34,7 & 23 & 10,6 & 0 & 0 & 216 & 100 & 739 & 864 & 85,53 & $\begin{array}{c}\text { Sangat } \\
\text { Baik }\end{array}$ \\
\hline & $\begin{array}{l}\text { Penggunaan } \\
\text { Masker }\end{array}$ & 14 & 158 & 73,1 & 44 & 20,4 & 0 & 0 & 0 & 0 & 216 & 100 & 764 & 864 & 88,43 & $\begin{array}{c}\text { Sangat } \\
\text { Baik }\end{array}$ \\
\hline & & 15 & 84 & 38,9 & 83 & 38,4 & 50 & 22,2 & 0 & 0 & 216 & 100 & 685 & 864 & 79,28 & $\begin{array}{c}\text { Sangat } \\
\text { Baik }\end{array}$ \\
\hline & & 16 & 54 & 25 & 99 & 45,8 & 61 & 28,2 & 0 & 0 & 216 & 100 & 635 & 864 & 73,50 & $\begin{array}{c}\text { Sangat } \\
\text { Baik }\end{array}$ \\
\hline & $\begin{array}{l}\text { Istirahat } \\
\text { Cukup }\end{array}$ & 17 & 76 & 35,2 & 100 & 46,3 & 60 & 27,8 & 0 & 0 & 216 & 100 & 724 & 864 & 83,80 & $\begin{array}{c}\text { Sangat } \\
\text { Baik }\end{array}$ \\
\hline & & 18 & 29 & 13,4 & 74 & 34,3 & 100 & 46,3 & 13 & 6 & 216 & 100 & 551 & 864 & 63,77 & Baik \\
\hline & & 19 & 34 & 15,7 & 79 & 36,6 & 95 & 44 & 0 & 0 & 216 & 100 & 563 & 864 & 65,16 & Baik \\
\hline & $\begin{array}{l}\text { Etika batuk } \\
\text { dan bersin }\end{array}$ & 20 & 147 & 68,1 & 58 & 26,9 & 0 & 0 & 0 & 0 & 216 & 100 & 762 & 864 & 88,19 & $\begin{array}{c}\text { Sangat } \\
\text { Baik }\end{array}$ \\
\hline & & 21 & 78 & 36,1 & 73 & 33,8 & 60 & 27,8 & 0 & 0 & 216 & 100 & 651 & 864 & 75,35 & $\begin{array}{c}\text { Sangat } \\
\text { Baik }\end{array}$ \\
\hline & & 22 & 72 & 33,3 & 59 & 27,3 & 64 & 29,6 & 21 & 9,7 & 216 & 100 & 614 & 864 & 71,06 & Baik \\
\hline & $\begin{array}{l}\text { Menjaga } \\
\text { Kebersihan }\end{array}$ & 23 & 156 & 72,2 & 35 & 62,50 & 9 & 16,07 & 3 & 5,36 & 216 & 100 & 750 & 864 & 86,81 & $\begin{array}{c}\text { Sangat } \\
\text { Baik }\end{array}$ \\
\hline & Lingkungan & 24 & 134 & 62 & 43 & 76,79 & 8 & 14,29 & 1 & 1,79 & 216 & 100 & 682 & 864 & 78,94 & $\begin{array}{c}\text { Sangat } \\
\text { Baik }\end{array}$ \\
\hline & & 25 & 0 & 0 & 0 & 0 & 36 & 16,7 & 169 & 78,2 & 216 & 100 & 241 & 864 & 27,89 & Cukup \\
\hline & & 26 & 131 & 60,6 & 42 & 19,4 & 0 & 0 & 29 & 13,4 & 216 & 100 & 679 & 864 & 78,59 & $\begin{array}{c}\text { Sangat } \\
\text { Baik }\end{array}$ \\
\hline & $\begin{array}{l}\text { Jaga jarak } \\
\text { aman }\end{array}$ & 27 & 98 & 45,4 & 81 & 37,5 & 37 & 17,1 & 0 & 0 & 216 & 100 & 709 & 864 & 82,06 & $\begin{array}{c}\text { Sangat } \\
\text { Baik }\end{array}$ \\
\hline & & 28 & 0 & 0 & 51 & 23,6 & 146 & 67,6 & 0 & 0 & 216 & 100 & 445 & 864 & 51,50 & Baik \\
\hline & Jumlah & & 86 & 41 & 65 & 30 & 47 & 22 & 17 & 7 & 216 & 100 & 644 & 864 & 74,47 & $\begin{array}{c}\text { Sangat } \\
\text { Baik }\end{array}$ \\
\hline
\end{tabular}

Keterangan gambar:

SCR : Skor capai responden

SI : Skor ideal

SNI : Skor nilai ideal

Dari Tabel 5 di atas dapat dilihat bahwa untuk variabel PHBS diperoleh tingkat capai sebesar 74,47\%, artinya Penerapan perilaku hidup bersih dan sehat(PHBS) Mahasiswa PGSD FKIP UIR di era pandemi covid19 berdasarkan variabel yang diteliti berada dalam kategori sangat baik. Bila dlihat dari pernyataan yang dijawab oleh responden untuk kriteria sangat selalu (SL) sebesar $40 \%$ atau 86 orang, kriteria sering (SR) sebesar 30\% atau 65 orang, kriteria pernahkadang-kadang (KD) sebesar 22\% atau 48 orang, kriteria tidak sebesar $8 \%$ atau 17 orang. Perilaku hidup bersih dan sehat seharusnya diterapkan didalam kehidupan sehari- 
DOI: https://doi.org/10.31004/basicedu.v6i1.2153

hari, apalagi pada kondisi pandemi saat ini. Penerapan perilaku hidup bersih dan sehat dapat mengurangi resiko terpaparnya virus covid-19. Adapun tujuan dari penerapan perilaku hidup bersih dan sehat adalah sebagai upaya menciptakan dan melestarikan perilaku hidup yang berorientasi kepada kebersihan dan kesehatan dimasyarakat, agar masyarakat dapat mandiri dalam mencegah dan menanggulangi maslah-masalah kesehatan yang dihadapinya (Kemenkes, 2011).

Penelitian-penelitian mengenai perilaku hidup bersih dan sehat telah banyak dilakukan terutama pada masa pandemi ini. diharapkan dengan demikian dapat menyadarkan masyarakat untuk dapat menerapkan perilaku hidup bersih dan sehat ini didalam kehidupannya sehari-hari terutama pada masa pandemi. penelitian yang dilakukan oleh (Maiti \& Bidinger, 1981) menunjukan pentingnya penerapan hidup bersih dan sehat di era pandemi dimana hasil tulisannya pencegahan penularan virus ini dapat dicegah dengan melakukannya dari hal-hal yang sederhana seperti cuci tangan dengan baik dan benar, menerapkan etika batuk, serta menjaga kesehatan dan sistem kekebalan tubuh. PHBS merupakan salah satu starategi dalam pencegahan penyebaran covid-19 yang sangat efektif dan mudah dilakukan oleh semua lapisan masyarakat. Kemudian penelitian yang dilakukan oleh (Wahyu \& Nisah, 2021) dimana hasil penelitiannya menunjukkan bahwa hasil rata-rata penerapan perilaku hidup bersih dan sehat (PHBS) saat pandemi covid-19 anak kelompok bermain pada sebesar 57,70 - 60,54\% sudah menerapkan hidup bersih dan sehat. Oleh karena itu, penelitian ini perlu dikembangkan agar dapat memberi acuan kepada orang tua untuk mengajarkan para anak agar hidup bersih dan sehat disaat pandemi ini.

Gambaran lebih jelasnya deskripsi Penerapan perilaku hidup bersih dan sehat (PHBS) Mahasiswa PGSD FKIP UIR di era pandemi covid-19 dapat dilihat pada diagram batang berikut ini.

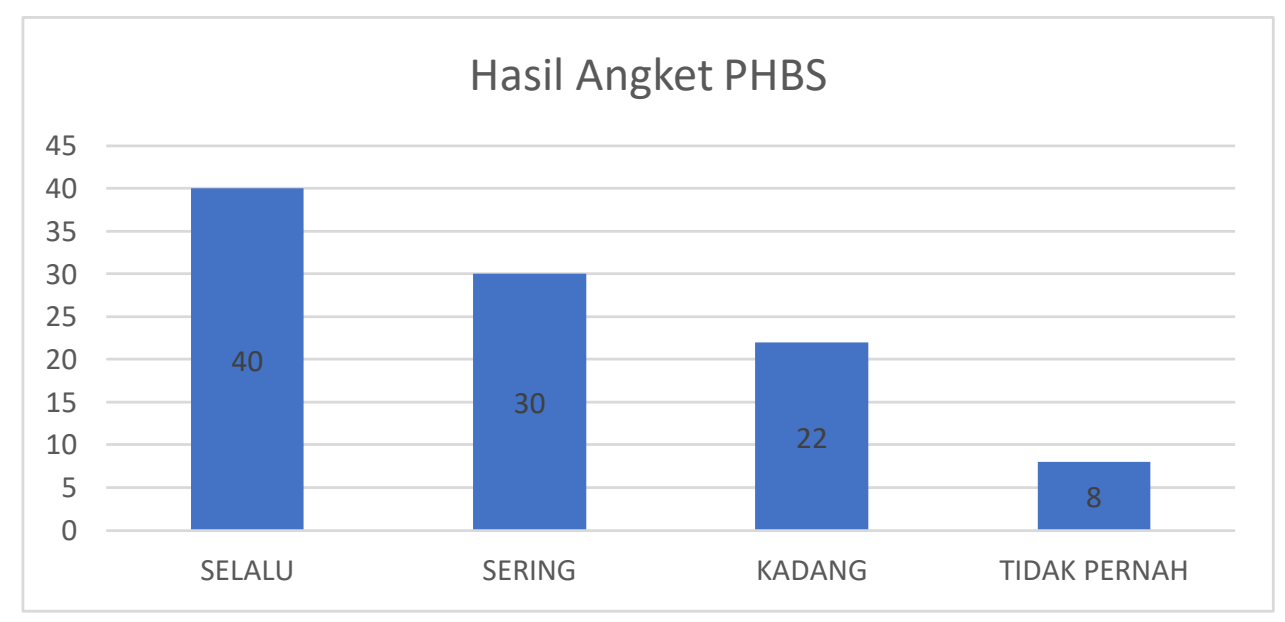

\section{Diagram Batang Penerapan perilaku hidup bersih dan sehat (PHBS) Mahasiswa PGSD FKIP UIR di era pandemi covid-19}

Data hasil penelitian yang dimaksudkan untuk menggambarkan hasil-hasil pengumpulan data yaitu tenang penerapan perilaku hidup bersih dan sehat (PHBS) Mahasiswa PGSD FKIP di Era Pandemi Covid-19. Analisis faktor dibagi menjadi makanan sehat, olahraga teratur, sering cuci tangan, hindari menyentuh wajah, penggunaan masker, istirahat cukup, etika batuk dan bersin, menjaga kebersihan lingkungan, dan jaga jarak aman. Berdasarkan hasil yang ditemukan dari dari 7 indikator menjadi 28 item pernyataan yang disampaikan didalam proposal bahwa masing-masing pernyaaan mendapatkan hasil yang berbeda-beda. Pernyataan pertama dari 216 responden di dapat hasil 76,39\% berada pada kategori sangat baik.

Berdasarkan hasil yang ditemukan dari dari 7 indikator menjadi 28 item pernyataan yang disampaikan didalam proposal bahwa masing-masing pernyaaan mendapatkan hasil yang berbeda-beda. Untuk lebih jelas dapat di lihat pada tabel berikut ini: 
Penerapan Perilaku Hidup Bersih dan Sehat (PHBS) Mahasiswa PGSD di Era Pandemi Covid-19Fitriyeni

DOI: https://doi.org/10.31004/basicedu.v6i1.2153

\begin{tabular}{|c|c|c|c|}
\hline No. Soal & $\begin{array}{c}\text { Indikator perilaku hidup } \\
\text { bersih dan sehat }\end{array}$ & Hasil (persentase) & Kategori \\
\hline 1 & \multirow[t]{6}{*}{ Makanan sehat } & $76,39 \%$ & Sangat Baik \\
\hline 2 & & $86,11 \%$ & Sangat Baik \\
\hline 3 & & $93,29 \%$ & Sangat Baik \\
\hline 4 & & $80,32 \%$ & Sangat Baik \\
\hline 5 & & $28,70 \%$ & Cukup \\
\hline 6 & & $58,10 \%$ & Baik \\
\hline 7 & \multirow[t]{2}{*}{ Olahraga teratur } & $61,46 \%$ & Baik \\
\hline 8 & & $53,70 \%$ & Baik \\
\hline 9 & \multirow[t]{4}{*}{ Sering cuci tangan } & $87,96 \%$ & Sangat Baik \\
\hline 10 & & $93,98 \%$ & Sangat Baik \\
\hline 11 & & $97,11 \%$ & Sangat Baik \\
\hline 12 & & $88,31 \%$ & Sangat Baik \\
\hline 13 & Hindari menyentuh wajah & $85,53 \%$ & Sangat Baik \\
\hline 14 & \multirow[t]{3}{*}{ Pakai masker } & $88,43 \%$ & Sangat Baik \\
\hline 15 & & $79,28 \%$ & Sangat Baik \\
\hline 16 & & $73,50 \%$ & Sangat Baik \\
\hline 17 & \multirow[t]{3}{*}{ Istirahat cukup } & 74.50 & Sangat Baik \\
\hline 18 & & $83,80 \%$ & Sangat Baik \\
\hline 19 & & $63,77 \%$ & Baik \\
\hline 20 & \multirow[t]{3}{*}{ Etika batuk dan bersin } & $65,16 \%$ & Baik \\
\hline 21 & & $88,19 \%$ & Sangat Baik \\
\hline 22 & & $75,35 \%$ & Sangat Baik \\
\hline 23 & \multirow{4}{*}{$\begin{array}{c}\text { Menjaga kebersihan } \\
\text { lingkungan }\end{array}$} & $71,06 \%$ & Sangat Baik \\
\hline 24 & & $86,81 \%$ & Sangat Baik \\
\hline 25 & & $78,94 \%$ & Sangat Baik \\
\hline 26 & & $27,89 \%$ & Cukup \\
\hline 27 & \multirow{2}{*}{$\begin{array}{c}\text { Hindari berkerumun dan } \\
\text { jaga jarak aman }\end{array}$} & $82,05 \%$ & Sanagat Baik \\
\hline 28 & & $51,50 \%$ & Baik \\
\hline
\end{tabular}

Berdasarkan hasil dari keseluruhan 28 pernyataan diperoleh bahwa penerapan perilaku hidup bersih dan sehat (PHBS) Mahasiswa PGSD FKIP di Era Pandemi Covid-19 sudah dikategorikan sangat baik. Hal ini terlihat dari item-item pernyataan yang sudah di ananlisis oleh peneliti. Dari analisis menunjukkan hasil 74,47, di mana hasil ini pada kategori sangat baik. Sehingga dapat disimpulkan bahwa penerapan perilaku hidup bersih dan sehat (PHBS) Mahasiswa PGSD FKIP di Era Pandemi Covid-19 sudah sangat baik. Seperti halnya penelitian yang dilakukan oleh (Anhusadar \& Islamiyah, 2020) dalam penelitian yang berjudul penerapan perilaku hidup bersih dan sehat anak usia dini di tengah pandemi covid-19, hasil penelitiannya menunjukan $100 \%$ orang tua melihat sangat penting penerapan perilaku hidup bersih dan sehat selama masa pandemi covid-19, sebanyak $98 \%$ atau 50 responden sudah mengetahui program perilaku hidup bersih dan sehat sedangkan $2 \%$ atau 1 responden yang belum mengetahuinya, penerapan perilaku hidup bersih dan sehat pada anak usia dini di lingkungan keluarga di tengah pandemi ini sangat baik. Selanjutnya artikel yang ditulis oleh (Ardiyanto et al., 2020) dimana hasil penelitiannya dosen PGSD Universitas PGRI Semarang telah melaksanakan perilaku hidup bersih dan sehat baik sebelum maupun selama pandemi covid 19 yakni dengan tetap berolahraga dan menjaga pola hidup sehat dan bersih. Jenis olahraga yang banyak dilakukan selama 

Fitriyeni

DOI: https://doi.org/10.31004/basicedu.v6i1.2153

masa pandemi covid 19 dengan prsentase tertinggi adalah senam, jogging dan bersepeda. Sedangkan untuk aktivitas fisik di rumah dengan presentase tertinggi yang banyak dilakukan adalah membersihkan rumah dan memasak. Dengan menerapkan pola hidup bersih dan sehat serta rutin berolahraga rata-rata minimal 30 menit perhari dosen PGSD Universitas PGRI Semarang percaya diri bahwa dengan tubuh yang bugar sehat karena berolahraga akan terhindar dari pandemi covid 19.

Pembiasaan perilaku hidup bersih dan sehat dapat membantu individu dalam menjaga kesehatannya dan dapat meminimalkan individu terhadap paparan virus covid-19, ini sejalan dengan (Maryunani, 2017) manfaat penerapan perilaku hidup bersih dan sehat sebagai berikut ini:

1. Mencegah timbulnya penyakit dan masalah kesehatan lainnya.

2. Menanggulangi penyakit dan masalah kesehatan lainnya, untuk meningkatkan derajat kesehatan.

3. Memanfaatkan layanan kesehatan.

4. Mengembangkan dan menyelenggarakan upaya kesehatan bersumber masyarakat.

Penerapan perilaku hidup bersih dan sehat sudah selayaknyaknya kita terapkan dalam kegiatan seharihari, karena ini akan memberikan dampak baik terhadap diri sendiri maupun orang lain dan juga lingkungan. Apalagi pada era pandemi seperti saat ini, perilaku hidup bersih dan sehat seperti makanan sehat, olahraga teratur, sering cuci tangan, hindari menyentuh wajah, memakai masker, istirahat yang cukup, etika batuk dan bersin, menjaga kebersihan lingkungan, hindari kerumunan dan jaga jarak aman yang ini merupakan indikator perilaku hidup bersih dan sehat dari tatanan pendidikan. Masih banyak terdapat indikator-indikator penerapan hidup bersih dan sehat lainya baik yang berasal dari tatanan rumah tanggaseperti penelitian oleh (Asrianti, Afiah, Muliyana, 2019) terdapat beberapa indicator tatanan rumah tangga yaitu jamban, olahraga, konsumsi sayur dan buah, merokok, tempat sampah, pemberantasan sarang nyamuk.

Perilaku hidup bersih dan sehat yang berasal dari tatanan tempat kerja ada beberapa indikator seperti penelitian oleh (Cahyawati \& Saniathi, 2021) yaitu: perilaku menggunakan masker keluar rumah atau tempat kerja, melepaskan masker saat bekerja, menggunakan alat pelindung diri yang memadai saat bekerja, menggunakan pakaian khusus saat bekerja, mencuci tangan dengan sabun pada air mengalir selesai bekerja, menjaga jarak aman 2 meter dengan orang sekitar, menggunakan cairan desinfektan selama bekerja, menerapkan etika batuk dan bersin yang benar, langsung mandi dan keramas selepas pulang kerja, berjabat tangan dengan orang lain, aktif melakukan kegiatan diluar rumah.

Untuk pencegahan penyebaran virus covid-19, perlu dilihat penerapan perilaku hidup bersih dan sehat dari berbagai tatanan kehidupan seperti yang dikemukakan oleh (Handayani et al., 2020) bahwa didalam protokol kesehatan harus memuat perlindungan kesehatan individu yang didalamnya terdapat untuk meningkatkan daya tahan tubuh dengan menerapkan Perilaku Hidup Bersih dan Sehat (PHBS) seperti mengkonsumsi gizi seimbang, aktivitas fisik minimal 30 menit sehari dan istirahat yang cukup (minimal 7 jam), serta menghindari faktor risiko penyakit, berikutnya juga dinyatakan oleh (Kemenkes RI, 2021) untuk meningkatkan imunitas tubuh atau kekebalan tubuh maka dapat melakukan hal berikut: konsumsi gizi seimbang, tidak merokok, suplemen vitamin, aktivitas fisik atau senan ringan, istirahat cukup, mengendalikan penyakit penyerta dan ini merupakan indikator perilaku hidup bersih dan sehat. Ini juga didukung oleh (Karo, 2012) yang dalam artikelnya PHBS merupakan starategi yang dapat mencegah penyebaran Covid-19, masyarakat terus dihimbau untuk meningkatkan prilaku hidup bersih dan sehat dalam upaya pencegahan penyebaran Covid-19, karenaperilaku masyarakat sangat berperan penting dalam penurunan angka penyebaran Covid-19. PHBS merupakansalah satu starategi dalam pencegahan penyebaran Covid-19 yang sangat efektif dan mudah dilakukan oleh semua lapisan masyarakat. Rekomendasi pemerintah terus menghimbau gerakan PHBS menjadi kunci pencegahan penyebaran Covid-19 pada masa pandemik ini. Melakukan PHBS diharapkan penyebaran Covid-19 dapat dihambat sehingga kejadian tidak bertambah. Oleh karena pentingnya perilaku hidup bersih dan sehat, perlu dilakukan pemberian informasi secara terus menerus 
DOI: https://doi.org/10.31004/basicedu.v6i1.2153

sehingga dapat meningkatkan pengetahuan seluruh lapisan masyarakat untuk menerapkan PHBS dalam kehidupan sehari-hari.

Sehingga dengan demikian dapat menggambarkan pola perilaku individu dalam memelihara kesehatannya dan lingkungannya, sehingga diharapkan nantinya bisa membuat suatu kebijakan yang tepat dalam menanggulangi penyebaran virus covid-19 di era pandemik ini dan sekaligus dapat memberikan edukasi pola perilaku hidup bersih dan sehat dalam semua tatanan kehidupan seperti pengabdian masyarakat yang dilakukan oleh (Zukmadini et al., 2020) dan hasil kegiatan menujukkan bahwa edukasi yang diberikan oleh fasilitator dapat meningkatkan pengetahuan anak-anak panti asuhan terhadap perilaku hidup bersih dan sehat dalam pencegahan COVID-19. Hal ini dapat dilihat dari persentase pengetahuan peserta sebelum diberikan edukasi yaitu sebesar 74,48\% yang kemudian meningkat menjadi $86,49 \%$ setelah diberikan edukasi.

\section{KESIMPULAN}

Setelah diadakan penelitian tentang Penerapan perilaku hidup bersih dan sehat (PHBS) Mahasiswa PGSD FKIP UIR di era pandemi covid-19, maka dapat diambil kesimpulan bahwa dari analisis menunjukkan hasil 74,47\%, di mana hasil ini pada kategori sangat baik. Sehingga dapat disimpulkan bahwa penerapan perilaku hidup bersih dan sehat (PHBS) Mahasiswa PGSD FKIP di Era Pandemi Covid-19 sudah sangat baik. dengan sangat baik nya pola penerapan hidup bersih dan sehat mahasiswa PGSD FKIP UIR dapat mencegah penyebaran virus covid-19 di era pandemi ini, dan sekaligus dapat memelihara kesehatan individu dalam kehidupannya.

\section{DAFTAR PUSTAKA}

Anhusadar, L., \& Islamiyah, I. (2020). Penerapan Perilaku Hidup Bersih Dan Sehat Anak Usia Dini Di Tengah Pandemi Covid 19. Jurnal Obsesi: Jurnal Pendidikan Anak Usia Dini, 5(1), 463. Https://Doi.Org/10.31004/Obsesi.V5i1.555.

Ardiyanto, A., Purnamasari, V., Sukamto, S., \& Setianingsih, E. (2020). Analisis Perilaku Hidup Bersih Dan Status Kebugaran Jasmani Di Era Pandemi Covid-19 Dosen PGSD. Jendela Olahraga, 5(2), 131-140. Https://Doi.Org/10.26877/Jo.V5i2.6216.

Argaheni, N. B. (2020). Sistematik Review: Dampak Perkuliahan Daring Saat Pandemi Covid-19 Terhadap Mahasiswa Indonesia. PLACENTUM: Jurnal Ilmiah Kesehatan Dan Aplikasinya, 8(2), 99. Https://Doi.Org/10.20961/Placentum.V8i2.43008.

Asrianti, Afiah, Muliyana, R. (2019). Jurnal Nasional Ilmu Kesehatan. Jurnal Nasional Ilmu Kesehatan, 1(2), $1-16$.

Cahyawati, P. N., \& Saniathi, N. K. E. (2021). Gambaran Perilaku Hidup Bersih Dan Sehat Pada Petugas Kebersihan Di Era Pandemi Covid-19. WICAKSANA: Jurnal Lingkungan Dan Pembangunan, 5(2), 87 91. Https://Doi.Org/10.22225/Wicaksana.5.2.2021.87-91.

Daniyanti, Dkk. (2020). Article Analisis Perilaku Hidup Bersih Dan Sehat ( PHBS ) Dalam Keperawatan, Stikes Ngudia Husada Madura, Indonesia Administrasi Kesehatan, Stikes Ngudia Husada Madura, Indonesia I. INTRODUCTION. 65-72.

Direktur Jenderal P2P, K. K. R. I. (2020). Pedoman Pencegahan Dan Pengendalian Coronavirus Disease (COVID-19). Germas, 0-115.

Handayani, D., Hadi, D. R., Isbaniah, F., Burhan, E., \& Agustin, H. (2020). Corona Virus Disease 2019. Jurnal Respirologi Indonesia, 40(2), 119-129. Https://Doi.Org/10.36497/Jri.V40i2.101.

Huang, C., Wang, Y., Li, X., Ren, L., Zhao, J., Hu, Y., Zhang, L., Fan, G., Xu, J., Gu, X., Cheng, Z., Yu, T., Xia, J., Wei, Y., Wu, W., Xie, X., Yin, W., Li, H., Liu, M., ... Cao, B. (2020). Clinical Features Of 
1194 Penerapan Perilaku Hidup Bersih dan Sehat (PHBS) Mahasiswa PGSD di Era Pandemi Covid-19Fitriyeni

DOI: https://doi.org/10.31004/basicedu.v6i1.2153

Patients Infected With 2019 Novel Coronavirus In Wuhan, China. The Lancet, 395(10223), 497-506. Https://Doi.Org/10.1016/S0140-6736(20)30183-5.

Karo, M. B. (2012). Perilaku Hidup Bersih Dan Sehat ( PHBS ) Strategi Pencegahan Penyebaran Virus Covid-19. 1-4.

Kemenkes. (2011). Peraturan Menteri Kesehatan Republik Indonesia.

Kemenkes RI. (2021). Ikhtisar Mingguan Covid-19. Kementrian Kesehatan Republik Indonesia, 1-15.

Maiti, \& Bidinger. (1981). Pentingnya Penerapan Phbs Dalam Menghadapi Pandemi Covid-19 Di Lingkungan Masyarakat. Journal Of Chemical Information And Modeling, 53(9), 1689-1699.

Maryunani. (2017). Perilaku Hidup Bersih Dan Sehat (PBHS). 36.

Nengsi, S., Masyarakat, F. K., Al, U., Mandar, A., \& Tradisional, P. (2021). Hubungan Perilaku Hidup Bersih Dan Sehat Terhadap Kejadian Covid-19 Di Pasar Wonomulyo Latar Belakang Pasar Termasuk Tempat-Tempat Umum Di Mana Banyak Orang Berkumpul Menjaga Suatu Bentuk Interaksi Atau Hubungan Satu Sama Lain. Interaksi Antara Penjual D. 127-137.

RI, K. (N.D.). Perilaku Hidup Bersih Dan Sehat (Phbs) Penguatan Kapabilitas Anak Dan Keluarga.

Sari, R. P., Tusyantari, N. B., \& Suswandari, M. (2021). Dampak Pembelajaran Daring Bagi Siswa Sekolah Dasar Selama Covid-19. Prima Magistra: Jurnal Ilmiah Kependidikan, 2(1), 9-15. Https://Doi.Org/10.37478/Jpm.V2i1.732.

Sugiyono. (2017). Statistik Untuk Penelitian (P. 17). Alfabeta.

Wahyu, D., \& Nisah, K. (2021). Pandemi Covid-19 Pada Anak Kelompok Bermain Tahun.

Zukmadini, A. Y., Karyadi, B., \& Kasrina, K. (2020). Edukasi Perilaku Hidup Bersih Dan Sehat (PHBS) Dalam Pencegahan COVID-19 Kepada Anak-Anak Di Panti Asuhan. Jurnal Pengabdian Magister Pendidikan IPA, 3(1). Https://Doi.Org/10.29303/Jpmpi.V3i1.440. 